ship on critical environmental issues, even when these cry out for an international response. Unlike fully fledged UN agencies such as the Food and Agriculture Organization or the World Health Organization, it is merely a 'programme', funded on a voluntary basis by the United Nations' member states.

Perhaps the outfit whose clout contrasts most vividly with UNEP's is the World Trade Organization, which is independent of the United Nations and arbitrates forcefully and effectively in disputes between its member states. UNEP, on the other hand, has neither ways to settle disputes nor mechanisms to enforce compliance with international environmental agreements such as the Convention on Biological Diversity.

UNEP's remit is more modest than that. Its job is to set and monitor standards for environmental protection and sustainable development around the world, in collaboration with local governments, scientists, non-governmental organizations and other interested parties. This responsibility stretches from biodiversity to climate change, from managing clean water to desertification, and from biosafety to problems posed by invasive species.

Under Töpfer, UNEP has improved its use of scientific information, and gained better access to the corridors of corporate power. On the downside, Töpfer has been drawn into distracting public disputes with other international bodies, over issues such as the administration of the Global Environment Facility, which finances environmental projects (see Nature 394, 4; 1998).

But UNEP's real problem is that it lacks the power to enforce the growing number of binding environmental agreements between nations. Beefing up the programme would probably involve a mandatory funding scheme based on the size of members' economies. Plans for this have been around for years, but they face significant obstacles, starting with the opposition of the United States, which currently contributes less than either the United Kingdom or Germany to UNEP's budget.

Such funding concerns hide a broader fear, by no means confined to the United States, that a more powerful UNEP would constrain the freedom that national governments currently enjoy to pollute pretty much as they please. This may be short-sighted, however. In the long run, national governments - and global capitalism, for that matter - might benefit from a strong international environmental body, a World Environmental Organization, if you will, with a remit to safeguard the future of the planet.

Töpfer has helped UNEP to build bridges with the worlds of business and finance, and
"UNEP's problem is that it lacks the power to enforce the growing number of binding environmental deals between nations." sought to convince business leaders that sustainable development and a healthy environment are in their interest, too.

The UN Summit could strengthen UNEP in the short term by merging it with the smaller, separate UN Division for Sustainable Development, currently a branch of the UN Department of Economic and Social Affairs. Secretary-General Kofi Annan then needs to appoint a heavyweight successor to Töpfer who can provide UNEP with energetic and determined leadership. That person should continue the policy of partnership with industry, while carefully guarding the organization's independence and further nurturing its credibility, in preparation for the day when national governments are ready to upgrade its status.

\section{All things equal}

Lack of affordable child care is a major impediment to women's careers, in science as elsewhere.

T he problem of under-representation of women in science, particularly at the most senior levels, is not going to go away. Public discussion of the issue often focuses on the extent to which girls are encouraged to pursue scientific interests at school, or to which they are discriminated against at work. But a more readily addressable impediment obstructs the career paths of many female researchers in early- and mid-career: the absence of suitable childcare arrangements.

The issue of child care tends to arise at a crucial juncture in women scientists' careers, and there is a growing consensus that it can play a significant role in thwarting scientific ambitions. All over the world, even as the number of women who pursue graduate education continues to grow, women remain under-represented in senior scientific positions. Among the major scientific nations, the situation is perhaps most acute in Japan and in Germany, where women make up $30 \%$ of those starting graduate school, but only $6 \%$ of full professors.

Advocacy groups such as the Association for Women in Science frequently emphasize the need to encourage girls to do science at school, and to mentor women scientists early in their careers. They should place equal emphasis on the need for affordable day care. Without it, women scientists can be forced to choose between putting off having children, or having their careers derailed by motherhood.
Most major universities and laboratories offer some child-care options, but uneven access and affordability prevent anything resembling a working, national system in all but a few countries. These programmes vary widely in quality and even the best ones have significant shortcomings, as we report in this issue (see page 446). Scandinavian nations and France offer some of the most comprehensive arrangements, but these are stretched thinly, with long waiting lists the norm. Most US universities offer child care, but the cost can be prohibitive to junior researchers.

Some employers have sought to address the affordability issue: the European Molecular Biology Laboratory in Heidelberg, Germany, for example, charges a fee of $10 \%$ of parents' combined income. Individual

\section{"Uneven access and affordability prevent a working, national child-care system in all but a few countries."} senior researchers have also chipped in to tackle the problem: Nobel laureate Christiane Nusslein-Volhard, head of the Max Planck Institute for Developmental Biology in Tübingen, set up a foundation last year to give five women scientists at the laboratory $€ 400$ (US\$ $\$ 40$ ) a month for babysitting and domestic help, when she noticed that talented female research assistants were dropping out of science once they had children.

The only systems that really work, though, involve government subsidies or tax incentives that enable the considerable cost of child care to be spread between the state, the employer and the employed. If women's representation in science is truly their objective, governments and research institutions must find a way to share the child-care load. 